\title{
DETERMINATION OF AGE, GROWTH AND MATURITY OF WHITE SEABREAM, DIPLODUS SARGUS (LINNAEUS, 1758) IN THE COAST OF NORTH SINAI
}

\author{
Ahmed. M. A ${ }^{1}$; Ghoneim, S. I. ${ }^{2}$; El-Dakar A. Y. ${ }^{2}$; Salem M. ${ }^{2}$ and El-Aiatt A $^{3}$. \\ 1.National institute of oceanography and fisheries (NIOF), Egypt. \\ 2.Dept. of Fish resources and aquaculture, Faculty of Environ. Agri. Sc., El-Arish, Suez \\ Canal University. Egypt. \\ 3.General authority for fish Resources development (GAFRD), Egypt.
}

\begin{abstract}
White seabream $D$. sargus $(\mathrm{n}=991)$ were caught along the Eastern Mediterranean between September 2010 and April 2012. Total length ranged from 11 to $38 \mathrm{~cm}$, represented age classes between 1 and 5 years. Total weight ranged from 12 to $840 \mathrm{gm}$. The scales were used to estimate the age. Age group (I) is dominant in the catch of D. sargus. Growth was supported using the back-calculation method. The growth performance index $(\Phi)$ showed a relatively high growth. Length at first maturity $\left(\mathrm{L}_{\mathrm{m}}\right)$ was $21.27 \mathrm{~cm}$ corresponding age $\left(\mathrm{t}_{\mathrm{m}}\right)$ 2.68 years. Length at first capture $\left(\mathrm{L}_{\mathrm{c}}\right)$ was $18.1 \mathrm{~cm}$ corresponding age $\left(\mathrm{t}_{\mathrm{c}}\right) 2.08$ years. So we have to increase the length at first capture to the length at first maturity in order to give fishes opportunity to spawn at first time at least.
\end{abstract}

Keywords: Eastern Mediterranean, age and growth, Diplodus sargus.

\section{INTRODUCTION}

The Mediterranean Sea is a semienclosed marine area with generally narrow continental shelves.It is seem as a whole has been referred to as an "evaporation basin" (Papaconstantinou and Farrugio, 2000). Information on stock composition and population dynamics of various fish species in Egyptian Mediterranean waters become of high importance for fisheries managers in order to increase fish production from marine areas.

There are about 64 fish families in Mediterranean waters of Egypt, which are represented by 202 species. Of these, family Sparidae is the most dominant comprising 21 species (Ibrahim and
Soliman, 1996). Seabreams (Sparidae) live in coastal waters world-wide, and sustain important recreational and commercial fisheries (Fischer et al., 1987). They could be found in a wide variety of marine habitats, from rocky to sand bottoms, at depths between 0 to 500 meters, although they are more common at less than 150 meters deep. (Gonçalves, 2000; Gomes et al., 2001; Sousa et al., 2005 and Ribeiro et al., 2006).

White seabream, Diplodus sargus, was found in the commercial fisheries throughout the long coast of Sinai in the Southern East part of Mediterranean Sea. It occurs in coastal rocky reef areas (Bauchot and Hureau, 1986). Age information is important as it forms $t$ he basis for the calculations of growth and 
productivity estimates (Campana, 2001), making it essential for fisheries management (Casselman, 1987 and Cailliet et al., 2001). The aim of this study is to establish growth key characteristics and maturity, where it is necessary for fisheries studies in the Eastern Mediterranean.

\section{MATERIALS AND METHODS}

During two seasons, 2010-2011 and 2011-2012, a total of 991 specimens of white seabream, D. sargus, (Total length, 11 to $38 \mathrm{~cm}$, total weight, 12 to 840 grams) were collected from mixed commercial catch by El-Dabba (El-kanar) gear which represented about 95\% from El-Arish Marin Seaport, and by the Long line gear 5\%. Several scales (5-6) were removed from below of pectoral fin, washed and stored dry in individually labeled envelopes.

In the laboratory, scales were washed with sodium hydrochloride (5\%) and cleaned with pure water and mounted dry between two glass slides, examined under a microscope $(5 \mathrm{X})$ to determine the age.

Also, was measured the total scale radius and the distance from the focus to each annulus using an eye piece micrometer. Total length (TL) was measured to the nearest $\mathrm{mm}$ and total weight (TW) recorded to the nearest one gram. Back calculations lengths done from scale measurements by using Lea's equation (1910):

$\mathrm{Ln}=(\mathrm{Sn} / \mathrm{S}) \mathrm{L}$, where, $\mathrm{Ln}$ is the length of fish at age "n", $\mathrm{Sn}$ is a magnified scale radius to " $n$ " annulus. $S$ : is a magnified total scale radius.

$\mathrm{L}$ is a fish length at capture. The relationship between length and weight was described by the potential equation as $\mathrm{W}=\mathrm{a}^{*} \mathrm{~L}^{\mathrm{b}}$ (Ricker, 1975), where (W) is proportional to a certain power (b) of the total body length (L). (a) \& (b) are constants whose values were estimated by the least square methods.

Constants of Von Bertalanffy's (1938) growth equation calculated by applying Gulland and Holt (1959) method.

Growth performance index $(\Phi)$ was studied using Munro and Pauly, (1983) maximum growth rate formula based on some biological and empirical consideration as:

For the asymptotic length Lo:

$\Phi^{\prime}=\log \mathrm{K}+2 \log \mathrm{L}_{\infty}$

For the asymptotic weight $\mathrm{W} \infty$ :

$\Phi=\log \mathrm{K}+2 / 3 \log$

$\mathrm{W}_{\infty} \mathrm{L} \infty$ is the asymptotic length, $\mathrm{W} \infty$ is the asymptotic weight and $\mathrm{K}$ is the growth coefficient.

The average length at first maturity $\left(\mathrm{L}_{\mathrm{m}}\right)$ calculated from an empirical relationship between length at first maturity and asymptotic length $\mathrm{L}_{\infty}$ (Froese and Binohlan, 2000).

$$
\log \mathrm{L}_{\mathrm{m}}=-0.1189+0.9157^{*}
$$

$\log \mathrm{L}_{\max }$ Where, $\mathrm{L}_{\max }$ : are the maximum length reached by fishes age at first maturity $\left(t_{m}\right)$ calculated from the length at first maturity using the inverse of the Von Bertalanffy's (1938) growth function.

The length at first capture (Lc), was determined from the accumulated catch curve as described in Pauly (1984).

\section{RESULTS}

\section{Age and growth.}

\subsection{Age determination}

Age determination of specimen as the annulus ring appeared as a thick dark zone.A total of five age groups were determined. The maximum group observed as $479(48.3 \%)$ fish corresponding year of life, followed by 330 fish corresponding $2^{\text {nd }}$ year of life. 
The $3^{\text {rd }}, 4^{\text {th }}$ and $5^{\text {th }}$ were represented by $18.4 \%$ only of total groups Table. (1).

\subsection{Length-Scale relationship}

Microscopic examination of scales growth rings showed a linear regression between length and scale radius of $D$. sargus represented by a straight line (Fig.1), the following formula representing this relationship:

$\mathrm{L}=-2.528+5.305 \mathrm{~S}, \mathrm{r}=0.983$ where, "L" is the total length $(\mathrm{cm})$ and "S" is the total scale radius (micrometer division).

\subsection{Length - Weight relationship}

The obtained equation found to be representing the relation between lengths and weights of $D$. sargus were:

$\mathrm{W}=0.011 \mathrm{~L}^{3.165} \mathrm{r}=0.976$.
This relation can be explaining graphically as in Figure. (2).The backcalculation length was determined of the white seabream D. sargus as $11.13,17.57$, 22.67, 27.12 and $29.82 \mathrm{~cm}$ for ages 1, 2, 3, 4 and 5 years respectively. It is clear that, the highest increment in length for $D$. sargus occurred at the first year of life $(11.13 \mathrm{~cm})$ and then declined rapidly, reaching its minimal value during the five year of life (Tablel and Fig 3) From Table (2) and Fig. (4), it is clear that the highest increment in weight for $D$. sargus occurred at the end of_fourth year of life as increment was (163.57 gm) and then declined rapidly thereafter, the backcalculated weight of D. sargus was 22.60 , $95.69,214.46,378.03$ and $510.92 \mathrm{gm}$, for ages 1, 2, 3, 4 and 5 years respectively.

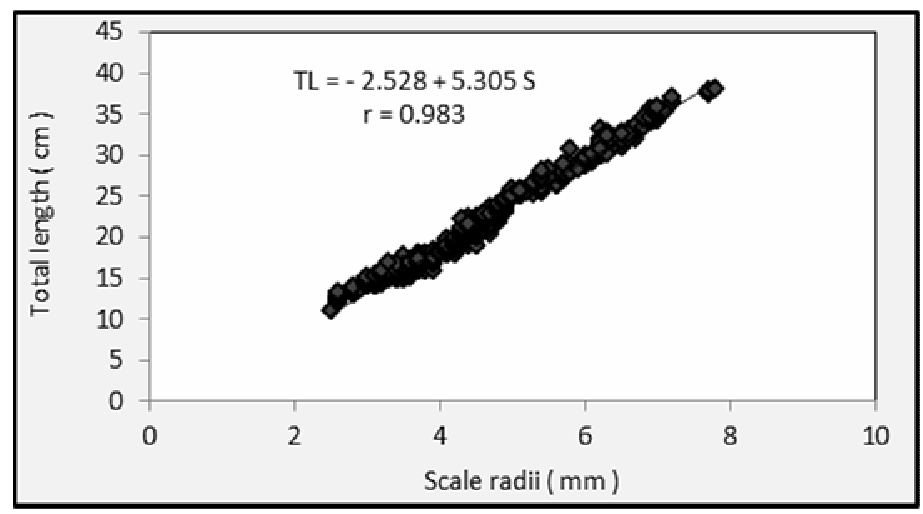

Fig.(1): Relation between length and scale radius of $D$. sargus from the Eastern Mediterranean.

Table (1): Back - calculated length of Diplodus sargus from the Eastern Mediterranean fishery

\begin{tabular}{|c|c|c|c|c|c|c|c|}
\hline \multirow{2}{*}{$\begin{array}{c}\text { Age } \\
\text { (year) }\end{array}$} & \multirow{2}{*}{ No. of Fishes } & \multirow{2}{*}{ Observed length } & \multicolumn{5}{|c|}{ Back calculated total length $(\mathrm{cm})$} \\
\hline & & & 1 & 2 & 3 & 4 & 5 \\
\hline $\begin{array}{l}1 \\
2 \\
3 \\
4 \\
5\end{array}$ & $\begin{array}{r}479 \\
330 \\
87 \\
54 \\
41 \\
\text { Averag } \\
\text { Standard De } \\
\text { Increme } \\
\% \text { increm }\end{array}$ & $\begin{array}{lr} & 15.88 \\
& 20.61 \\
& 27.53 \\
& 30.69 \\
& 34.55 \\
\text { en } & \\
\text { fiation } & \\
\text { ht } & \\
\text { ent } & \end{array}$ & $\begin{array}{l}11.13 \\
10.77 \\
11.48 \\
11.19 \\
11.81 \\
11.28 \\
+0.39 \\
11.13 \\
37.33\end{array}$ & $\begin{array}{l}17.57 \\
17.67 \\
17.90 \\
17.89 \\
17.76 \\
+0.16 \\
6.43 \\
21.57\end{array}$ & $\begin{array}{c}22.67 \\
22.70 \\
23.08 \\
22.81 \\
+0.23 \\
5.10 \\
17.11\end{array}$ & $\begin{array}{c}27.12 \\
27.50 \\
27.31 \\
+0.27 \\
4.45 \\
14.91\end{array}$ & $\begin{array}{c}29.82 \\
29.82 \\
0.00 \\
2.71 \\
9.08\end{array}$ \\
\hline
\end{tabular}




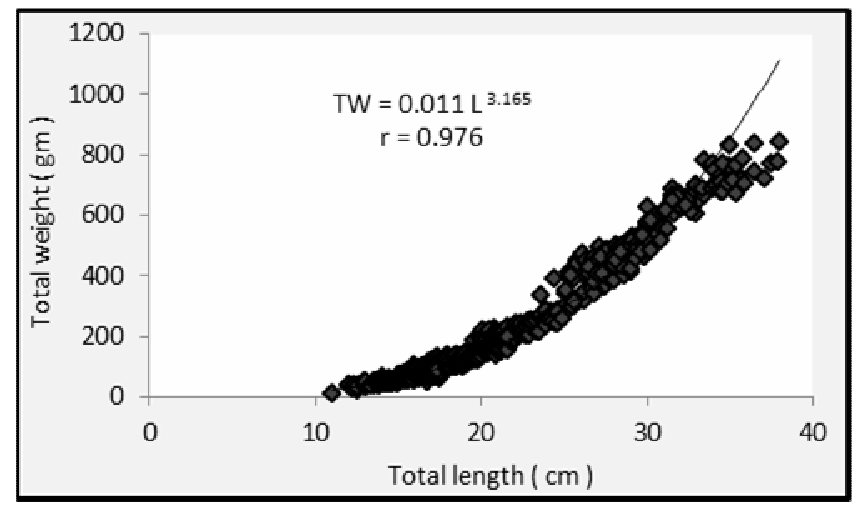

Fig. (2): Length - weight relationship of $D$. sargus from the Eastern Mediterranean.

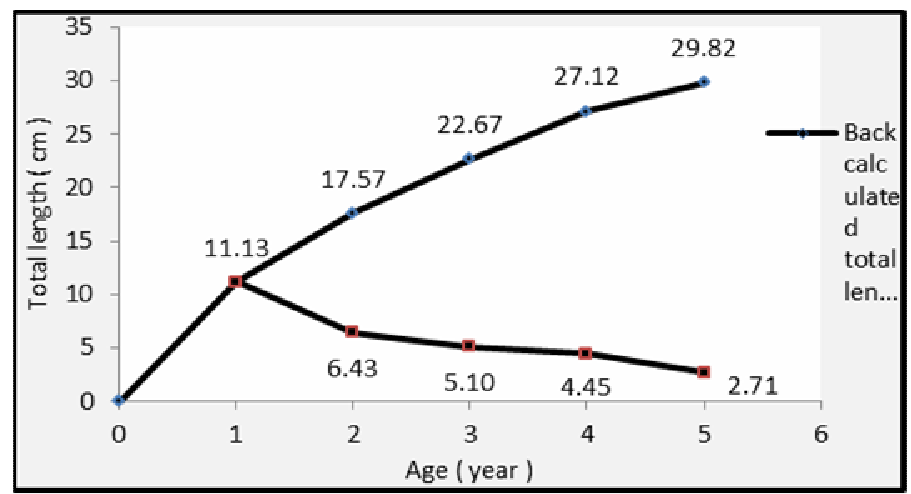

Fig. (3): Increment in length of Diplodus sargus from the Eastern Mediterranean fishery.

1.4 Theoretical growth in length and weight

For growth in length using the Von Bertalanffy's equation and we applied the Gulland and Holt (1959) method to estimate the Von Bertalanffy's equation constant such as $\mathrm{L}_{\infty}, \mathrm{K}$ and $\mathrm{t}_{\mathrm{o}}$ Table (3) as: $\mathrm{Lt}=40.94\left(1-\mathrm{e}^{-0.2460(\mathrm{t}+0.2904)}\right)$

And for growth in weight the result of $\mathrm{W}_{\infty}$ Table (3) as:

$\mathrm{Wt}=1392.1\left(1-\mathrm{e}^{-0.2460(\mathrm{t}+0.2904)}\right)^{3.165}$.

\subsection{Growth performance index $(\Phi)$}

The growth performance index $(\Phi)$ as defined by were computed for $D$. sargus in the Eastern Mediterranean and found to be 2.617 for length and 1.488 for weight.

\section{Estimation of length and age at first} maturity $\left(L_{m}\right.$ and $\left.t_{m}\right)$
Calculate age at first maturity from the length at first maturity by the inverse of the von Bertalanffy's (1938) growth function, for $D$. sargus in the Eastern Mediterranean the length $\left(\mathrm{L}_{\mathrm{m}}\right)$ was 21.27 cm corresponding age $\left(t_{m}\right) 2.68$ years.

\section{Estimation of length at first capture (Lc)}

The length at which the probability of capture is $50 \%$, length at first capture (Lc) of D. sargus was $18.1 \mathrm{~cm}$ corresponding age $\left(t_{c}\right) 2.08$ years, where it described graphically Fig. (5).

\section{DISCUSSION}

Knowledge of growth and growth variability is essential to the understanding of a stock's population dynamics. To achieve an accurate 
SINAI Journal of Applied Sciences (ISSN: 2314-6079) Vol.:(4) Is.:(1), Apr. 2015

assessment of these characteristics, several issues need to be addressed. The condition factor "K" which was considered another way for expressing the relationship between length and weight. Fisheries biologists study fish habitat and fish populations, learning about the natural conditions that fish live in and then extending their knowledge to determine how a fishery can be used sustainable (Jacot, 1920; Anderson 1958).

Scales are the most commonly used as it is easy to sample and read (Lagler, 1956). Also, to ease of removal and handling of scales and it can be taken without killing the fishes; as the case of studying age and growth for reared fish (Wassef, 1978). Data for body length and scale radius show a linear on their scatter diagram. For length-weight relationship of White Seabream in the Eastern Mediterranean fishery we found " $b$ " parameter $(b=3.165)$, positive allometric growth was observed as the value of (b) was more than 3. this results was agreement with El-Maghraby and Botros (1981) in the Egyptian Mediterranean water $(b=3.144)$, ManWai and Quignard, (1982) in the Gulf of Lion $(b=3.123)$ and Morato et al. (2001) in the Azores $(b=3.181)$ for both Males and Females, but less than that results which recorded by Mann (1992) in the South-East coast of South Africa $(b=3.242)$ and higher than that recorded by Lahlah, (2004) in the Egyptian Mediterranean (2007) in the Gulf of Tunis ( $b=3.051)$, Mahmoud et al. (2010) in Abu Qir bay $(b=2.942)$ and Benchalel and Kara (2012) in the Eastern cost of Algeria the 2.987).

Table(2): Back - calculated weight of Diplodus sargus from the Eastern Mediterranean fishery.

\begin{tabular}{cccccccc}
\hline \multirow{2}{*}{$\begin{array}{c}\text { Age } \\
\text { (year) }\end{array}$} & \multirow{2}{*}{ No. of Fishes } & \multirow{2}{*}{ Observed Weight } & \multicolumn{5}{c}{ Back calculated total weight ( gm ) } \\
\cline { 3 - 7 } & & & 1 & 2 & 3 & 4 & 5 \\
\hline $\mathbf{1}$ & 479 & 71.34 & 22.60 & & & & \\
$\mathbf{3}$ & 330 & 170.85 & 20.34 & 95.69 & & & \\
$\mathbf{4}$ & 87 & 434.10 & 24.91 & 97.53 & 214.46 & & \\
$\mathbf{5}$ & 54 & 569.28 & 22.95 & 101.58 & 215.29 & 378.03 & \\
& 41 & 710.80 & 27.26 & 101.31 & 226.92 & 395.12 & 510.92 \\
& & 23.61 & 99.03 & 218.89 & 386.58 & 510.92 \\
& Standard Deviation & 2.61 & 2.89 & 6.97 & 12.08 & 0.00 \\
& Increment & 22.60 & 73.09 & 118.77 & 163.57 & 132.89 \\
& \% increment & 4.42 & 14.31 & 23.25 & 32.02 & 26.01 \\
\hline
\end{tabular}

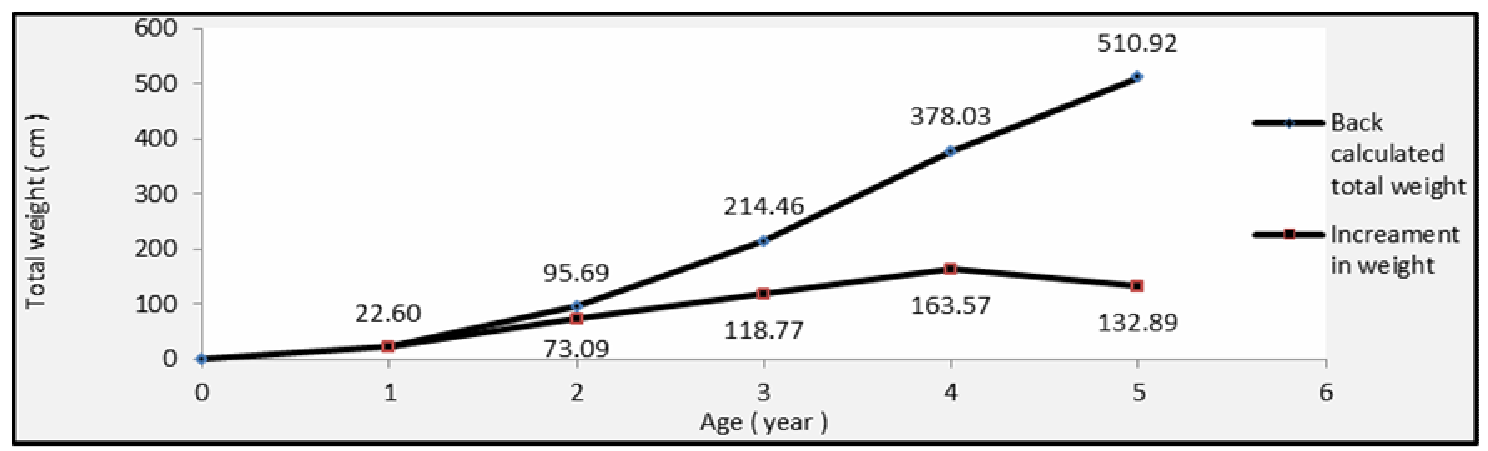

Fig. 4: Increment in weight of $D$. sargus from the Eastern Mediterranean fishery. 
Table (3): Constants of Von Bertalanffy's growth equation

\begin{tabular}{cc}
\hline Constants & Gulland and Holt (1959) \\
\hline $\mathbf{L}_{\infty}$ & 40.93 \\
$\mathbf{K}$ & 0.2460 \\
$\mathbf{t}_{\mathbf{0}}$ & -0.2904 \\
$\mathbf{W}_{\infty}$ & 1392.1 \\
\hline
\end{tabular}

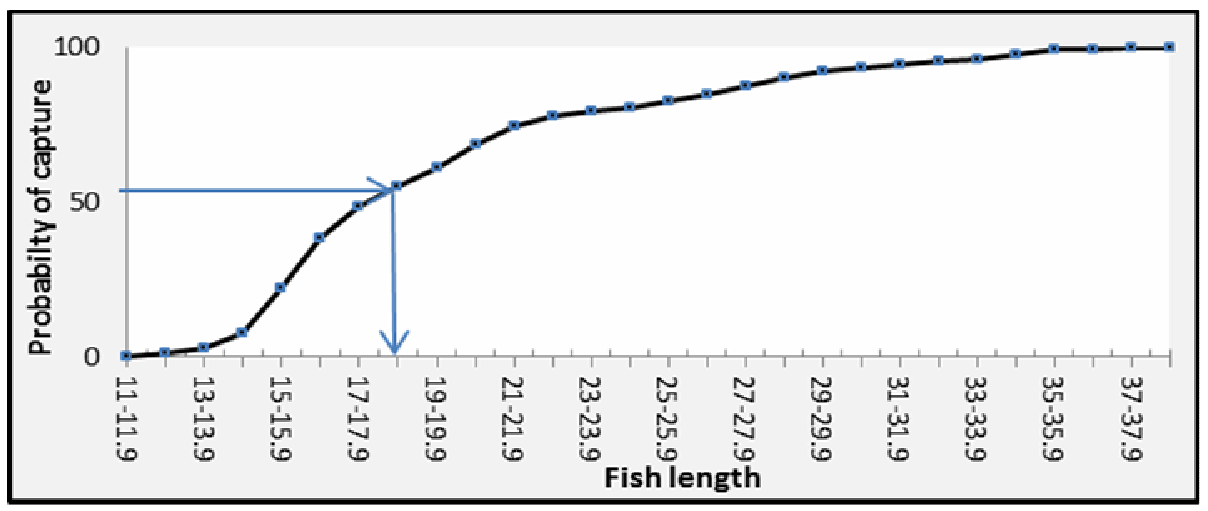

Fig. (5): Cumulated catch curve of $D$. sargus from the Eastern Mediterranean fishery.

Rosa et al. (2006) and Mcllwain et al. (2005) mentioned that the differences in length-weight relationships and growth parameters is due to age, sex, maturity and sampling period for the same species. Back-calculated methods have many advantages over the direct methods of estimating growth in fishes. This method has been widely adopted on a large number of species (Chugunova, 1959).

When comparing growth among species from different regions, the growth was faster in the Eastern Mediterranean area, as shown in Table (4). The back calculation of the total body weight at the end of each year of life in this study is agreement with El-Maghraby et al. (1982), more than Man-Wai and Quignard, (1982), and Mahmoud et al., (2010), and also Lahlah, (2004) as in Table (5).

From that results, indicated that, the growth in the Eastern Mediterranean coast is the highest comparing with the different locations. It may be related to the suitable of environment for this species and availability of food.

Also, the growth parameters (Lo, K and $\mathrm{t}_{0}$ ) and the growth performance index (Ф) of D. sargus were affected by that the short lifespan where from the large sample $(\mathrm{n}=991)$ no individuals were recorded older than 5 years of age.The growth performance index for $D$. sargus was $\Phi=2.617$ for length and 1.488 for weight.

This results was within the range of results from investigation of Pastor and Cuadros, (1996) where found $\Phi=2.63$ and Gordoa and Molí, (1997) where found $\Phi=2.64$. Other authors studied the growth performance index as $\Phi=2.42$, Man-Wai and Quignard (1982), $\Phi=$ 2.38, Mann and Buxton, (1997), $\boldsymbol{\Phi}=$ 2.50, Pajuelo and Lorenzo, (2002), and $\Phi=2.37$, Abecasis et al., (2008) and $\Phi=$ 2.30, Benchalel and Kara, (2012). In present work length and age at first 
maturity was $\left(\mathrm{L}_{\mathrm{m}}=21.27 \mathrm{~cm}\right.$ and $\mathrm{t}_{\mathrm{m}}=2.68$ years) other authors as Bauchot and Hureau (1986) found that $t_{m}=2$ years, with length about $17 \mathrm{~cm}$. Mann and Buxton (1998) measured the Fork length of D. sargus and it was $21.1 \mathrm{~cm} \mathrm{FL}$ corresponded age 3 years.

Morato et al., (2003) found $\mathrm{t}_{\mathrm{m}}=2.12$ years, with length as $16.73 \mathrm{~cm}$. Mouine et al., (2007) found $\mathrm{L}_{\mathrm{m}}=20.5 \mathrm{~cm}$ for males and $21.4 \mathrm{~cm}$ for females, corresponded age 4 years old.

Benchalel and Kara (2012) found $\mathrm{L}_{\mathrm{m}}=20 \mathrm{~cm}$ for females and $20.2 \mathrm{~cm}$ for males corresponds to an age of 4 years.

In conclusion the length at first capture (50\% of the fish are vulnerable to capture) for D. sargus was estimated at $18.1 \mathrm{~cm}$, while it attains its first sexual maturity at $21.27 \mathrm{~cm}$. It was noticed that the majority of D. sargus caught from the Eastern Mediterranean fishery were immature.
Therefore, in order to protect this species and to enable it to share at least for one time in reproduction, an urgent increasing in mesh size of used nets as well as the evaluation of all fishing techniques in the Eastern Mediterranean fishery and prohibiting the dangerous ones must be done.

\section{REFFERENCES}

Abecasis D.; L. Bentes; R. Coelho; C. Correia; P.G. Lino; P. Monteiro ; J.M.S. Gonçalves; J. Ribeiro and K. Erzini, (2008). Ageing Seabream: A comparative study between scales andotoliths. Fisheries Research. Vol. 89: $37-48$.

Anderson, W. W., (1958). Larval development, growth and spawning of striped mullt (Mugil cephalus) along the south Atlantic Coast of the United States. Fish. Bull. (U.S.). 59 (144): 501-519.

Table (4): Back calculation length of $D$. sargus in different locations.

\begin{tabular}{cccccccc}
\hline Author & $\mathbf{L}_{\mathbf{I}}$ & $\mathbf{L}_{\mathbf{I I}}$ & $\mathbf{L}_{\mathrm{III}}$ & $\mathbf{L}_{\mathbf{I V}}$ & $\mathbf{L}_{\mathbf{V}}$ & $\mathbf{L}_{\mathrm{VI}}$ & Location \\
\hline $\begin{array}{c}\text { El-Maghraby and Botros, } \\
\mathbf{1 9 8 1}\end{array}$ & 10.37 & 15.93 & 20.40 & 23.62 & 26.67 & 29.20 & Egypt Med. \\
Man-Wai and Quignard, 1982 & 10.90 & 16.50 & 20.30 & 23.20 & 25.20 & 26.70 & Gulf of Lion \\
Lahlah, 2004 & 9.44 & 12.47 & 14.86 & 16.67 & 18.33 & 20.43 & Egypt Med. \\
Mahmoud et al., 2010 & 11.42 & 15.96 & 19.57 & 22.35 & 24.44 & 25.98 & Abu Qir Bay \\
Present study & 11.13 & 17.57 & 22.67 & 27.12 & 29.82 & - & Eastern Med. \\
\hline
\end{tabular}

Table (5): Back calculation weight of $D$. sargus in different locations.

\begin{tabular}{cccccccc}
\hline Author & $\mathbf{W}_{\mathbf{I}}$ & $\mathbf{W}_{\mathrm{II}}$ & $\mathbf{W}_{\mathrm{III}}$ & $\mathbf{W}_{\mathrm{IV}}$ & $\mathbf{W}_{\mathbf{V}}$ & $\mathbf{W}_{\mathrm{VI}}$ & Location \\
\hline El-Maghraby et al., 1982 & 18.4 & 69.5 & 151.1 & 240.9 & 348.9 & 460.0 & Egypt \\
Man-Wai and Quignard, 1982 & 20.0 & 86.0 & 160.0 & 235.0 & 280.0 & 355.0 & Gulf of Lion \\
Lahlah, 2004 & 8.2 & 21.3 & 33.3 & 46.8 & 64.3 & - & Egypt \\
Mahmoud et al., 2010 & 26.8 & 71.7 & 130.6 & 193.1 & 251.2 & 300.5 & Abu Qir Bay \\
Present study & 22.6 & 95.7 & 214.5 & 378 & 510.9 & - & Eastern Med. \\
\hline
\end{tabular}


Bauchot, M.L. and J.C. Hureau, (1986). Sparidae. In P.J.P. Whitehead, M.L. Bauchot, J.C. Hureau, J. Nielsen and E. Tortonese (eds), Fishes of the North-eastern Atlantic and the Mediterranean, Vol. II, pp. 883-907. UNESCO.

Benchalel, W. and M. H. Kara, (2012). Age, growth and reproduction of the white seabream Diplodus sargus sargus (Linneaus, 1758) off the eastern coast of Algeria. J. Appl. Ichthyol. 29 (2013), 64-70.

Cailliet, G.M.; A.H. Andrews; E.J. Burton; D.L. Watters; D.E. Kline and L.A. Ferry-Graham, (2001). Age determination and validation studies of marine fishes: do deepdwellers live longer. Exp. Gerontol. 36, 739-764.

Campana, S.E., (2001).Accuracy, precision and quality control in age determination, including a review of the use and abuse of age validation methods. Journal of Fish Biology 59, 197-242.

Casselman, J.M.,(1987). Growth and relative size of calcified structures of fish. Transactions of the American Fisheries Society 119, 673-88.

Chugunova, N. I., (1959). Age and growth studies in fish. Izvestiya Akademii Nauk SSSR, Moskva. 132 pp.

El-Maghraby, A. M.; G. A. Botros, (1981). Maturation, spawning and fecundity of two sparid fish Diplodus sargus, L. and Diplodus vulgaris, Geoffer in the Egyptian Mediterranean waters. Bull. Nat. Inst. of Oceanogr. Fish., ARE 8(2), 5167.

El-Maghraby, A. M.; G. A. Botros; M. T. Hashem and E. A. Wassef, (1982). Age determination and growth studies of two sparid fish
Diplodus sargus, L. and Diplodus vulgaris, Geoffer in the Egyptian Mediterranean waters. Bull. Nat. Inst. of Oceanogr. Fish., ARE 7(3), 386394.

Fischer W.; M. Schneider and M.L. Bauchot, (1987). Fiches FAO d'identification des espèces pour les besoins de la pêche. (Rev. 1). Méditerranée et mer Noire. Zone de pêche 37. Vol. I. Végétaux et Invertébrés (FAO species identification cards for needs of fishing (Rev. 1). Mediterranean and Black sea. Fishing area 37. Vol. I Plants and Invertebrates). Rome, FAO, Vol. 1.1: 1-760 p.

Froese, R. and C. Binohlan, (2000). Empirical relationships to estimate asymptotic length, length at first maturity and length at maximum yield per recruit in fishes, with a simple method to evaluate length frequency data. J. Fish Biol. 56, 758773.

Gomes, M.C., Serrao, E., Borges, M.d.F., (2001). Spatial patterns of groundfish assemblages on the continental shelf of Portugal. ICES J. Mar. Sci. 58 (3), 633-647.

Gonçalves, J.M.S., (2000). Biologica Pesqueirae Dinamica Populacionalde Diplodus vulgaris (Geoffr) e Spondylio soma cantharus (L) (Pisces, Sparidae) na costa Sudoeste de Portugal. Universdado do Algarve, UCTRA, Faro, Ph.D. Thesis, 369 pp.

Gordoa, A. and B. Moli, (1997). Age and growth of the sparids D. vulgaris, $D$. sargus and $D$. annularis in adult populations and the differences in their juvenile growth patterns in the North Western Mediterranean Sea. Fish. Res. 33: 123 - 129.

Gulland, J. A. and S. J. Holt, (1959). Estimation of growth parameters for 
data at unequal time intervals. J.Cons.CIEM, 25(1): 47-49.

Ibrahim, M. A. and I.A. Soliman, (1996). Check list of the bony fish species in the Mediterranean waters of Egypt. Bull. Nat. Inst. of Oceanogr. \& Fish. A.R.E. (22): 43 57.

Jacot, A.P., (1920).Age, growth and scale characters of the mullets, Mugil cephalus and Mugil curema. Trans. Amer. Fish. Soc. 39(3): 199-229.

Lagler, K. F., (1956). Fish Water fishery biology. W. G. Brown co. Dubuque, Lowd, $42 \mathrm{p}$.

Lahlah, M., (2004). Ecological studies on two fish species inhabiting coastal Seaweed meadous in Alexandria waters. Ph.D. Thesis. Alex. Univ. Fac. of Scince.

Lea, E., (1910). On the methods used in the herring investigations. Publ. Circonstance, Cons. Int. Explor. Mer., 53: 7-174.

Mahmoud, H. H; A. M. Osman; A. A. Ezzat and A. M. Saleh,(2010). Fisheries biology and management of Diplodus sargus sargus (Linnaeus, 1758) in Abu Qir Bay, Egypt. Egy. J. Aquat. Res., 36(1), 123-131.

Mann, B. Q. and C.D. Buxton, (1997).Age and growth of Diplodus sargus capensis and D.cevinus hottentotus (Sparidae) on the Tsitsikamma coast, S. Africa. Cybium 21(2): $135-147$.

Mann, B. Q. and C.D. Buxton, (1998). The reproductive biology of Diplodus sargus capensis and D. cervinus hottentotus (Sparidae) off the southeast cape coast, South Africa. Cybium, 22: 31-47.

Mann, B. Q., (1992). Aspect of the biology of tow inshore sparid fishes
(Diplodus sargus capensis and Diplodus cervinus hottentotus) off the South-East coast of South Africa. M.Sc. Thesis. Rhodes University.

Man-Wai, R. and J.P. Quignard, (1982). The seabream Diplodus sargus (Linnaeus, 1758) in Gulf of Lion: growth of the seabream and characteristics of landings from the commercial fishing grounds of Sete and Grau-du-Roi. Rev. Trav. Inst. Peches Marit. Nates 46 (3): 173 - 194.

Mcllwain, J. L., M. R. Claereboudt, H. S. AL-Oufi, S. Zaki, G.S. Goddard, (2005). Spatial variation in age and growth of the Kingfish (Scomberomorus commerson) in the coastal waters of The Sultanate of Oman. Fish. Res., 73: 283 - 298.

Morato T.; P. Afonso; P. Lourinho; J.P. Barreiros; R.S. Santos and R.D.M. Nash, (2001). Weight length relationship for 21 coastal fish species of Azores, North Eastern Atlantic. Fish. Res. 50: 297 - 302.

Morato, T.; P. Afonso; P. Lourinho; R.D.M. Nash and R.S. Santos, (2003). Reproductive biology and recruitment of the sea bream in the Azores. J. Fish. Biol., 63: 59-72.

Mouine, N.; P. Francour; M. Ktari and N. CH-Marzouk,(2007). The reproductive biology of Diplodus sargus sargus in the Gulf of Tunis (central Mediterranean). Scientia Marina. 71(3): 461 - 469.

Munro, J. L. and D. Pauly, (1983). A simple method for comparing growth of fishes and invertebrates. ICLARM Fishbyte, 1 (1) : 5 - 6 .

Pajuelo, J. G. and J. M. Lorenzo, (2002). Growth and age estimation of Diplodus sargus cadenati (Sparidae) off the Canary Islands. Fish. Res. 59, 93-100. 
Papaconstantinou, C. and H. Farrugio, (2000). Fisheries in the Mediterranean Marine Science, Vol $1 / 1,: 5-18$.

Pastor, C. M. and V. M. L. Cuadros, (1996). Edad, crecimiento y reproducci'on de Diplodus sargus Linnaeus, 1758 -- (Sparidae) en aguas asturianas (norte de Espana). Bollt. Instituto Espanol Oceanografia 12 (1), $65-76$.

Pauly, D. (1984). Length-converted catch curves: a powerful tool for fisheries research in the tropics (Part III: Conclusion). Fishbyte, Newsletter of the Network of Tropical Fisheries Scientists 2(3): 8-10.

Ribeiro, J., Bentes, L., Coelho, R., Gonc,alves, J.M.S., Lino, P.G., Monteiro, P., Erzini, K., (2006). Seasonal, tidal and diurnal changes in fish assemblages in the Ria Formosa lagoon (Portugal). Estuar. Coast. Shelf Sci. 67 (3), 461-474.

Ricker, W.E., (1975). Computation and interpretation of biological statistics of fish populations. Bull. Fish. Res. Broad of Canada. (191): 2 - 6.

Rosa, D., G. José, A. Pajuelo, M. L. José and G. R. Antonio,(2006). Age and growth of the sharpsnout seabream Diplodus puntazzo (Cetti, 1777) inhabiting the Canarian archipelago, estimated by reading otoliths and by backcalculation. Fisheries research, 81, Iss. (2-3):142-148.

Sousa, P., Azevedo, M., Gomes, M.C., (2005). Demersal assemblages off Portugal: mapping, seasonal, and temporal patterns. Fish. Res. 75, 120137.

Von Bertalanffy, L., (1938). A quantitative theory of organic growth. (Inquiries on growth laws II). Hum. Biol. 10:181-213.

Wassef, E. A., (1978). Biological and physiological studies on marine and acclimatized fish Sparus aurata. Ph.D. thesis. Cairo Univ. Fac. Of Sci. pp 225. 


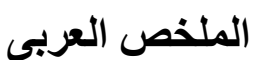

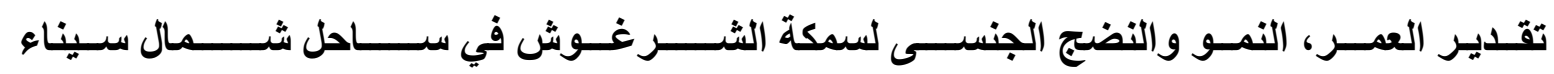

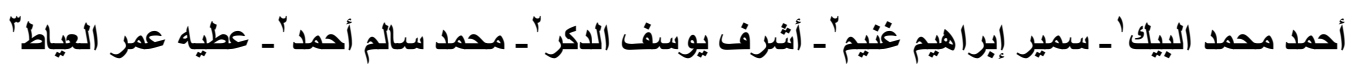

$$
\begin{aligned}
& \text { ا ـ المعهد القومى لعلوم البحار. }
\end{aligned}
$$

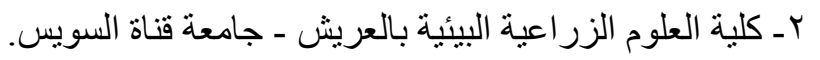

$$
\begin{aligned}
& \text { بـ الهيئة العامة لتتمية الثروة السمكية. }
\end{aligned}
$$

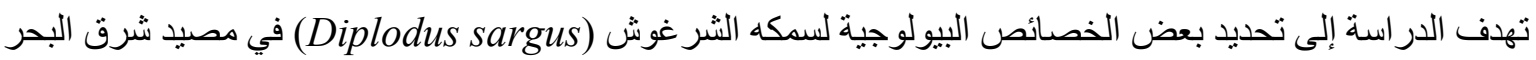

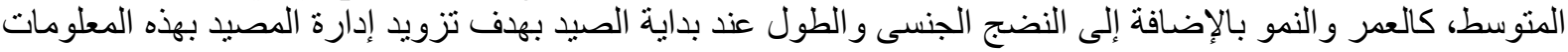

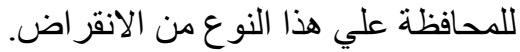

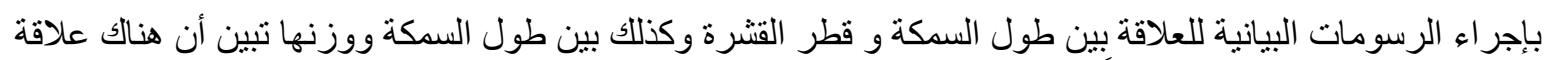

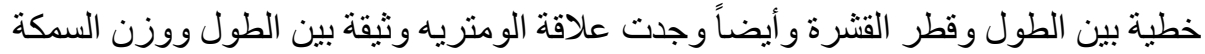

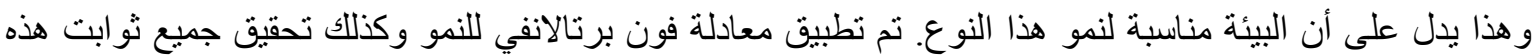

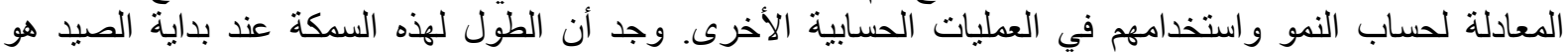

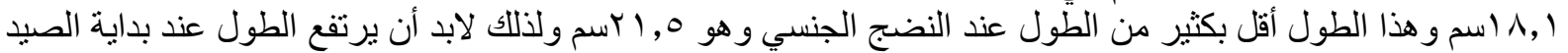

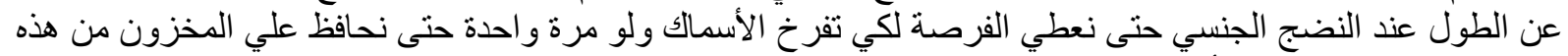
السمكة الاقتصادية وذات الأهمية التسويقية العالية. الكلمات الإسترشادية: العمر ، النمو، النضج الجنسي، سمكه الثر غوشيه. 
El-Beak, et al. 